\title{
INVESTIGAÇÕES GEOFÍSICAS NA PEDREIRA DE GRANITO ORNAMENTAL, NO MUNICÍPIO DE CAPÃO BONITO-SP, UTILIZANDO-SE OS MÉTODOS GPR E ELETRORRESISTIVIDADE
}

\author{
Abad Oliveira Souza Júnior \\ Orientador: Dr. Jorge Luís Porsani (IAG/USP) \\ $101 p$ - Dissertação (Mestrado) - Defesa 20.03.2002
}

\begin{abstract}
RESUMO. Neste trabalho foi estudado a utilização dos métodos geofísicos de Ground Penetrating Radar(GPR) e eletrorresistividade como ferramentas para 0 imageamento de zonas de fraturas, juntas de alívio e caracterização do topo da rocha sã. Os trabalhos foram executados em uma pedreira de granito ornamental, pertencente à empresa SOMIBRÁS (Sociedade Brasileira de Mineração S/A), localizada no Município de Capão Bonito - SP. 0 imageamento em subsuperfície permitiu subsidiar os projetos de engenharia de minas, tais como: cubagem do volume de solo que deverá ser retirado ("bota fora"), direcionamento da frente de lavra, avaliação da metodologia de lavra, cubagem da jazida explorável e possíveis impactos ambientais. Os resultados do método GPR, permitiram localizar zonas de fraturas, com a presença de fraturas inclinadas e subhorizontais com baixo mergulho, em até cerca de $25 \mathrm{~m}$ de profundidade. Também foram localizados matacões em subsuperfície ao longo da estrada de acesso à frente de lavra e no alto da pedreira. Identificou-se em um dos perfis GPR, realizado no alto do morro, a intrusão de um dique de diabásio, confirmado pelo reconhecimento deste dique em campo. Na frente de lavra da pedreira discriminou-se uma zona pouco fraturada, entre as "juntas de alívio" (planos de bancadas), sendo esta muito promissora para a extração de blocos graníticos. Os resultados das Sondagens Elétricas Verticais (SEV's) permitiram investigar até 37m de profundidade, possibilitando assim compor o seguinte modelo de camadas: i) Solo de alteração da rocha granítica com presença de ar; ii) Solo de alteração da rocha com presença de matacões; iii) Rocha granítica fraturada com a presença de água, iv) Rocha granítica Sã, v) Rocha granítica Sã, com a presença de juntas de alívio e zonas de fraturas preenchidas com água. Após uma interpretação integrada, os resultados geofísicos obtidos com o método GPR e Sondagens Elétricas Verticais foram comparados com dados geológicos de superfície, permitindo assim obter um modelo geofísico que auxilie num melhor aproveitamento na exploração da jazida.
\end{abstract}

ABSTRACT. In this work, it was studied the utilization of the geophysical methods of Ground Penetrating Radar (GPR) and eletro-resistivity as tools for the visualization of zone of fractures, relief's joints and characterization of the top of a granitic bed rock. The survey was carried out were in a quarry of ornamental granite, belonging to the company SOMIBRÁS (Brazilian Society of Mining S/A), located in the Municipal district of "Capão Bonito SP". Imaging the subsurface will allow to compliment the engineering projects, such as: estimation the soil volume that should be excavated, front direction of plows mining, evaluation of the methodology of exploration, evaluation the impact of this exporation on the enviroment. The results of GPR method, they allowed to locate fractures zones, which are critically inclined fractures and subhorizontal with moderate dip, down to $25 \mathrm{~m}$ of depth. It also enable to locate buried granitc plugs in subsurface along the access highway ahead also were located plowing mining and in the top of the quarry. One of GPR profiles of the top of the quarry identified an intrusion of a diabasic dike, which has been confirmed to out crop on the surface. It in front of plows mining of the quarry the GPR profile identified a less fractured zone, between the "relief's joints", being this very promising to the extraction of granitic blocks. The results of Vertical Electric Soundings (VES) provided information down to $37 \mathrm{~m}$ of depth. Based on the results, a stratified model of the area has been inferred as follows: i) Dry soil with a fragments of altered granitic rock; ii) Alteration soil and rock fragments with a granitic plugs; iii) Granitic rock fractured with water saturated, iv) Dry granitic rock mass, v) Granitic bed rock, with the presence of relief's joints and fracture zones that are filled by water. After an integrated interpretation, the geophysical results obtained with GPR method and Vertical Electric Soundings (VES) were compared with geological data of surface, allowing thus to obtain a geophysical model that assists in a better utilization in the exploration of the mine. 